\title{
Incorporating Water Sensitive Urban Design (WSUD) practices into the planning context: the conceptual case for lot-scale developments
}

\author{
R. T. S. Nunes ${ }^{1}$, J. H. A. Prodanoff ${ }^{2}$, B. Nunes $^{3}$ \& M. A. V. Freitas ${ }^{1}$ \\ ${ }^{I}$ Environmental Planning Group, Energy Planning Program, \\ Rio de Janeiro Federal University, Brazil \\ ${ }^{2}$ Water Resources and Environment Department, \\ Polytechnic School, Brazil \\ ${ }^{3}$ Operations and Information Management Group, \\ Aston Business School, Aston University, UK
}

\begin{abstract}
In recent decades, a number of sustainable strategies and polices have been created to protect and preserve our water environments from the impacts of growing communities. The Australian approach, Water Sensitive Urban Design (WSUD), defined as the integration of urban planning and design with the urban water cycle management, has made considerable advances on design guidelines since 2000. WSUD stormwater management systems (e.g. wetlands, bioretentions, porous pavement etc), also known as Best Management Practices (BMPs) or Low Impact Development (LID), are slowly gaining popularity across Australia, the USA and Europe. There have also been significant improvements in how to model the performance of the WSUD technologies (e.g. MUSIC software). However, the implementation issues of these WSUD practices are mainly related to ongoing institutional capacity. Some of the key problems are associated with a limited awareness of urban planners and designers; in general, they have very little knowledge of these systems and their benefits to the urban environments. At the same time, hydrological engineers should have a better understanding of building codes and master plans. The land use regulations are equally as important as the physical site conditions for determining opportunities and constraints for implementing WSUD techniques. There is a need for procedures that can make a better linkage between urban planners and WSUD
\end{abstract}


engineering practices. Thus, this paper aims to present the development of a general framework for incorporating WSUD technologies into the site planning process. The study was applied to lot-scale in the Melbourne region, Australia. Results show the potential space available for fitting WSUD elements, according to building requirements and different types of housing densities.

Keywords: water sensitive Urban design; WSUD technologies; Urban planning and design; lot-scale; procedures; Australia.

\section{Introduction}

Growth population and urbanization directly affects our catchments and our urban water cycle. New buildings and houses are built every day, creating more impervious surfaces. These changes increase the volume of the stormwater runoff (consequent impact on flooding) and cause degradation on our surface waters.

In Australia, the term Water Sensitive Urban Design (WSUD) is commonly used to reflect a new paradigm in the planning and design of urban environments that is 'sensitive' to the issues of water sustainability and environmental protection. The objectives of WSUD relating to stormwater management include [1]:

- Reduce potable water demand: through water efficient appliances, rainwater and greywater reuse;

- Protect natural water systems: treating urban stormwater to meet water quality objectives for reuse and/or discharge to surface waters.

- Preserving the natural hydrological regime of catchments;

- Reduce runoff and flood protection: reduce runoff and peak flows from urban developments by local detention measures and minimizing impervious areas;

- Integrate stormwater treatment into the landscape: use stormwater in the landscape by incorporating multiple use corridors that maximize the visual and recreational amenity of developments.

Over the last few years, WSUD technologies (such as bioretention systems, wetlands, rainwater tanks, etc) have made significant improvements on design guidelines, including in hydrological and treatment performances - e.g. MUSIC software [2-4]. However, institutional capacity related to technical knowledge is the main challenge for incorporating WSUD practices into the urban landscape. Urban planners, designers, landscape architects have an essential contribution to make in supporting WSUD strategies towards more sustainable developments.

Thus, this paper aims to present the development of a general framework for incorporating WSUD technologies into the site planning process. This framework contains 3 stages that lead to assessment of the potential area available for fitting WSUD elements, according to building requirements and different types of housing densities. This study was applied to a conceptual case for lot-scale developments in Doncaster Hill situated in Manningham City, Melbourne metropolitan region (Victoria State, Australia). 


\section{Methods}

A framework entitled Benchmarking for Liveable Urban Environments (or in short BLUE Plan) has been proposed that is a simple procedure for incorporation of Water Sensitive Urban Design systems into local urban plans. It consists of three distinctive stages (Figure 1), that should be applied to a city/region that is examined:

Stage 1 - Review of WSUD technical characteristics for the region;

Stage 2 - Review of the local urban planning regulations and processes; and,

Stage 3 - Development of criteria for integrating WSUD into the local urban landscapes.

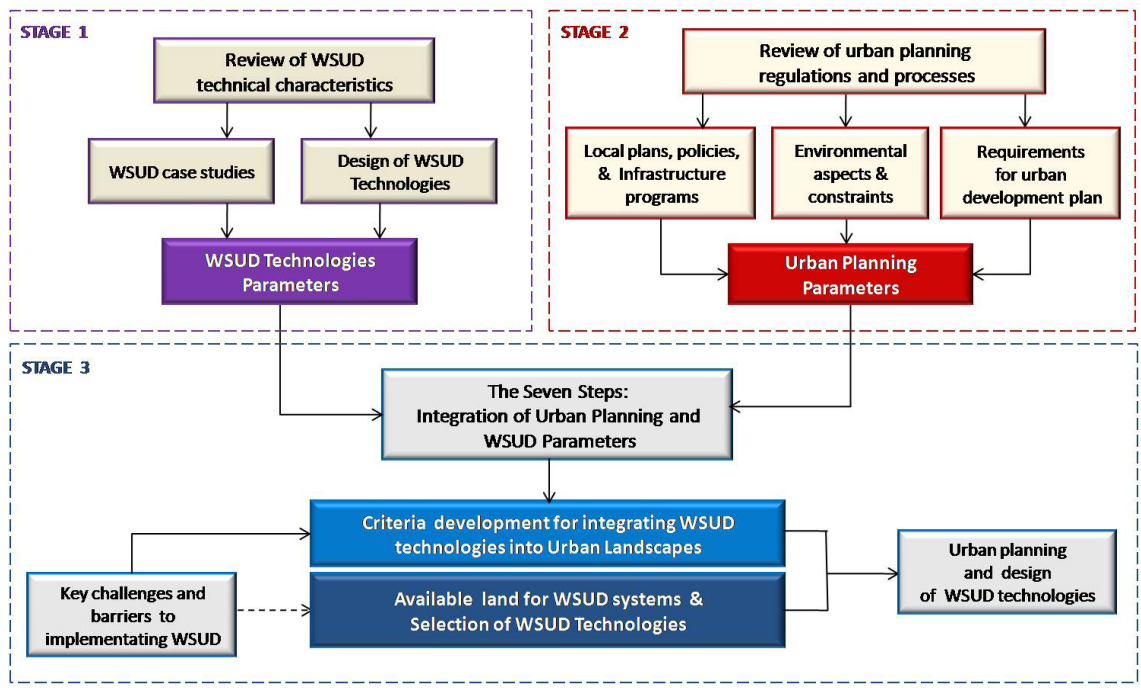

Figure 1: The BLUE Plan overall framework.

The most significant parameters that govern this framework are: (i) scale (lot, streetscape or precinct) and (ii) land use (residential, commercial, industrial, public land use). The BLUE Plan therefore has to distinguish between the scale and land use for each specific region.

\section{Stage 1 - Review of local WSUD technical characteristics}

The first stage of BLUE Plan aims to review the objectives and technical characteristics of WSUD technologies for the region in question. This includes review of local WSUD design guidelines, as well as local case studies. The procedures used for fitting WSUD systems have to be examined to determine how much space is required for implementation of each WSUD technology in the context of local climate and catchment characteristics (e.g. review of design curves for the region), as well as agreed targets (e.g. required treatment 
performance of hydrological effectiveness). This also includes opportunities and constraints of the technologies in relation to the site characteristics.

The eleven design parameters listed in Table 1 should be identified for each WSUD technology within the regional context (these parameters were chosen to represent a 'short technical profile' of each WSUD technology). Some of the listed parameters may not be relevant for a particular technology.

Table 1: $\quad$ The design parameters of the WSUD technologies.

\begin{tabular}{lc}
\hline & Design characteristics of a given WSUD technology for a city/region \\
\hline 0 & Purpose of the WSUD technology: e.g. treatment for waterway protection, treatment \\
1 & for stormwater harvesting, flood protection, storage, reuse, etc; \\
0 & Suitability for a given urban scale: lot, streetscape, precinct, or regional; \\
2 & \\
0 & Strategic location within the urban catchment \\
3 & (e.g. near to the source or end-of-pipe) \\
0 & Impervious catchment area that it treats (minimum size required of WSUD \\
4 & technology to achieve treatment and hydrological targets) \\
0 & Hydrological performance (hydraulic loading, return period of rainfall even it \\
5 & treats, requirements for flood protections) \\
0 & Treatment performance \\
6 & (expected outflow concentrations and/or pollutant removal rates) \\
0 & Any pre-treatment requirements \\
7 & Opportunities and barriers in relation to catchment characteristics \\
0 & (site soil properties, slopes, local vegetation requirements) \\
8 & Maintenance requirements \\
0 & Infrastructure and services existent or required \\
9 & Amenity and social implications \\
1 & (e.g. does the technology have aesthetic or cultural values etc) \\
0 &
\end{tabular}

\section{Stage 2 - Review of local urban planning regulations}

The second stage of BLUE Plan should begin with a review of the general principles of urban planning in the region/city. This should include environmental aspects, as well as opportunities and constraints for new developments (greenfield sites) and/or redevelopments (brownfield sites). This is used to identify the eleven parameters on 'Environmental Aspects and Constraints' that are listed in Table 2.

The town planning, environmental and infrastructure legislations should be examined in detail. The planning and building requirements must be determined, such as standard lot dimensions, street blocks design, minimum pervious area of the allotments, design and geometry of streets, size and demand for public areas (e.g. recreation, parks), etc. In this way, the further eleven urban planning parameters, that were named here as 'General Requirements for Urban Development Plan' were identified as listed in Table 2. As above, they should be examined for each specific site using local planning regulations. 
Table 2: $\quad$ The Urban planning parameters.

\begin{tabular}{|c|c|c|}
\hline \multicolumn{3}{|c|}{ Environmental Aspects and Urban Planning Requirements } \\
\hline \multirow{11}{*}{$\begin{array}{l}\text { Environmental } \\
\text { aspects } \\
\text { and } \\
\text { constraints }\end{array}$} & 01 & Population, densities and growth rates \\
\hline & 02 & Physical characteristics of the urban catchment \\
\hline & 03 & Marine environment \\
\hline & 04 & $\begin{array}{l}\text { Vegetation - parks, isolated trees, native flora } \\
\text { (including fauna or wildlife) }\end{array}$ \\
\hline & 05 & Microclimate \\
\hline & 06 & Topography - elevation, slope, orientation \\
\hline & 07 & Geology - soil properties \\
\hline & 08 & Water quality \\
\hline & 09 & Air quality \\
\hline & 10 & Natural hazards (floodplain, erosion, landslide, etc) \\
\hline & 11 & Nuisances (noises, odours, unsightly views) \\
\hline \multirow{11}{*}{$\begin{array}{c}\text { General } \\
\text { Requirements } \\
\text { for Urban } \\
\text { Development } \\
\text { Plan }\end{array}$} & 12 & $\begin{array}{l}\text { Location and stage of development: Brownfield } \\
\text { (retrofit) or Greenfield (new site) }\end{array}$ \\
\hline & 13 & $\begin{array}{l}\text { Scale ( lot, streetscape, precinct, regional), size and } \\
\text { shape }\end{array}$ \\
\hline & 14 & $\begin{array}{l}\text { Zoning, subdivisions, easements, reserves and site } \\
\text { restrictions }\end{array}$ \\
\hline & 15 & $\begin{array}{c}\text { Land Use - Residential, Industrial, Business, Mixed } \\
\text { use and Public land }\end{array}$ \\
\hline & 16 & $\begin{array}{l}\text { Density and/or typology of building types (single or } \\
\text { multifamily houses, multifamily towers or mixed-use } \\
\text { residential/commercial development) }\end{array}$ \\
\hline & 17 & $\begin{array}{c}\text { Heritage, cultural landmark or particular } \\
\text { neighbourhood character and other significant site } \\
\text { amenities }\end{array}$ \\
\hline & 18 & Standard building requirements \\
\hline & 19 & Parking and driveway design and requirements \\
\hline & 20 & $\begin{array}{l}\text { Minimum requirement for open space (public and } \\
\text { private), recreation and parks }\end{array}$ \\
\hline & 21 & Urban design elements and landscaping requirements \\
\hline & 22 & Infrastructure system and utility services \\
\hline
\end{tabular}

\section{Stage 3 - Development of criteria for integrating WSUD into the local urban landscapes}

The last objective stage is to develop clear quantifiable criteria for integration of the WSUD technologies (designed according to local technical requirements) into the local urban environments (satisfying requirements of the local urban planning regulations). This means estimation of available space/land for implementation of WSUD at a given scale, as well as suitable identification of WSUD technologies for the given planning framework.

The following steps have been identified in the process: 
I. Urban planning policies - check the legal and environmental conditions of the site;

II. Site conditions - describe the local main features base on Table 2;

III. Building requirements - investigate measures, dimensions, geometry and requirements on the urban planning regulations (and other Development Control Plans) according to the specific scale, land use and region/country;

IV. Design and site layout analysis - list all the needs along with uses and afterwards analyse the layout with all the elements likely build into the site;

V. Opportunities and constraints to implementing WSUD technologies verify that the area available, local infrastructure and physical conditions conform with the parameters in table 1, and examine if the site is adequate for implementing WSUD technologies;

VI. Land availability for WSUD - as a result of the previous steps, the percentage of the urban area is determined that can be taken up by the WSUD technologies;

VII. Selection of WSUD technology - select the type of WSUD technologies suitable for the site and available area (using the WSUD technical parameters defined in Table 1).

\section{Application}

The BLUE Plan framework can be applied to 3 different scales: (i) allotment, (ii) streetscape and (iii) precinct for urban areas in general. So this paper presents its application at the lot-scale for Doncaster Hill in Manningham City, situated in Melbourne Metropolitan Region, Victoria State, Australia. The Doncaster Hill development is a 58-hectare area located approximately 12 kilometers from the Melbourne Central Business District (CBD). According to Melbourne 2030 Planning for sustainable growth [5], it has been identifying as a Principal Activity Centre and one of the growing shires of Melbourne Metropolitan Region [6].

Stage 1: Firstly, the main WSUD design guidelines were explored for WSUD stormwater technologies [1,3], including examples of WSUD systems applied in lot-scale developments in Melbourne region [4, 7]. Secondly, Ecologically Sustainable Development (ESD) design principles were studied, in particular, the Sustainability Guidelines focus on WSUD elements for housing landscape design developed by Manningham City Council for Doncaster Hill Activity Centre.

Stage 2: References based on the principles for smart growth, New Urbanism [8, 9] and Melbourne 2030 Plan [5], were important contributors to this methodology. Planning publications about the water and density debate [10-12] were also included at this stage. In addition, an average of lot sizes for different types of housing density was examined across Australia, Brazil and USA [11, 12], as well as examples of Australian and Brazilian Master Plans [13-15]. The planning regulations required for the application of the framework in this 
Australian case study were: Manningham Planning Scheme [13] and Doncaster Hill strategies [6].

Stage 3: This stage comprises the seven steps to incorporating WSUD technologies into the urban planning process. In this phase, a conceptual case study for lot-scale development of WSUD implementation into a retrofit area of Doncaster Hill (Manningham City) was investigated.

In general, typical residential allotments vary from 300 squares meters to 1,000 square meters. The majority of residential lot sizes in metropolitan Melbourne range from 500 square meters up to 1000 square meters [16]. In Doncaster Hill, the predominant lot sizes are closer to 1000 square meters, so 3 lots were examined with this similar size but with distinct housing densities (low, medium and high) established by the local planning regulations. To understand more about built form and different categories of residential density, table 3 demonstrates typical categories of housing density found in Australia.

Table 3: $\quad$ Typical housing density in Australia.

\begin{tabular}{ccc}
\hline Housing Density & Storeys & $\begin{array}{c}\text { Dwellings per hectare } \\
\text { (dw/ha) }\end{array}$ \\
\hline Low Density Development & $1-2$ & $11-22 \mathrm{dw} / \mathrm{ha}$ \\
Medium Density Development & $3-4$ & $23-45 \mathrm{dw} / \mathrm{ha}$ \\
High Density Development & 5 or more & Greater than $45 \mathrm{dw} / \mathrm{ha}$ \\
\hline
\end{tabular}

Source: Understanding Residential Densities, South Australia Government [12].

The last steps of Stage 3, spatial analysis according to site form, housing densities and current building requirements, is carried out to show the potential area available for incorporating a variety of WSUD engineering practices into lot-scale development in Doncaster Hill.

\section{Results and discussion}

Results from BLUE Plan framework applied to lot-scale developments show how is possible to incorporate WSUD stormwater technologies into small areas, according to local urban planning regulations, natural site features and WSUD design characteristics (demonstrated in the parameters of Table 1 and 2). Table 4 presents the principal parameters examined of each step (described in stage 3) that led to the development of the criteria for fitting WSUD systems within allotments of Doncaster Hill neighborhood. Step I provides the planning control legislation base used for Manningham City, mainly Doncaster Hill. This step also provides all the detailed information needed for Step II and III. Step II describes the general features of the development. Although this step shows just one example of lot-scale with high density, this study reveals outcomes for three housing density types in Step VI. Step III then highlights the standard building requirements for residential areas where the most significant parameters used for the criteria were 'Site Coverage Area' (60\%) and 'pervious surface' (20\%). 
Table 4: BLUE plan criteria for integrating WSUD technologies into lotscale of Doncaster Hill.

\begin{tabular}{cc}
\hline Steps & Parameters examined and criteria developed \\
\hline $\begin{array}{c}\text { I. Urban Planning } \\
\text { Policies }\end{array}$ & Master Plan-Manningham Planning Scheme (clauses 54, 55, \\
& 56) [13]; \\
& Doncaster Hill Strategy [6]
\end{tabular}

II. Site Conditions

A. Stage of Development: Redevelopment area

B. Land Use: residential area

C. Scale: lot scale

D. Housing Density: high density

A. Max Building Site Coverage Area (SC) $=60 \%$

B. Min Street setbacks $=5 \mathrm{~m}$ from front site boundary

III. Building

Requirements

C. Min Side setbacks $=$ total $4.5 \mathrm{~m}$ from sides boundaries

D. Min Rear setbacks $=5 \mathrm{~m}$ from rear boundary

E. Min Private open space $=20 \%$

F. Min Permeable surface $=20 \%$

G. Max Building Height $=29 \mathrm{~m}$ (or 10 stories)

\begin{tabular}{|c|c|}
\hline $\begin{array}{l}\text { IV. Design and Site } \\
\text { Layout Analysis }\end{array}$ & $\begin{array}{c}\text { - SC = dwelling, verandah, garage, visitors parking, any } \\
\text { other roofed building (e.g. garden shed); } \\
\text { - Ornamental garden, veggie garden, lawn (grass paver); } \\
\text { - Outdoor paving, driveways, footpaths, carport; } \\
\text { - Outdoor entertaining area: swimming pool, sports court, } \\
\text { playground, BBQ area, party hall, etc; } \\
\text { - Gas, dust-bin, generator and other equipment or service } \\
\text { area }\end{array}$ \\
\hline $\begin{array}{l}\text { V. Opportunities } \\
\text { and Constraints } \\
\text { to Implement } \\
\text { WSUD Technologies }\end{array}$ & $\begin{array}{c}\text { A. Infiltration capacity of the soil; } \\
\text { B. Topography and slope site; } \\
\text { C. Infrastructure available; } \\
\text { D. Area Available, lot size, housing density. } \\
\text { E. Other parameters present in Table } 1\end{array}$ \\
\hline $\begin{array}{c}\text { VI. Land } \\
\text { Availability for } \\
\text { WSUD Technology }\end{array}$ & See Table 5 \\
\hline $\begin{array}{l}\text { VII. Selection of } \\
\text { WSUD Technology }\end{array}$ & See Table 6 \\
\hline
\end{tabular}

In addition, Step IV identified all the potential needs for a multifamily building with a maximum of 10 stories that can accommodate around 40 families in the same allotment in Doncaster Hill. Step V verified that the lot sizes in Doncaster Hill are not a constraint for implementing WSUD systems. However, it is necessary to check the other parameters in Table 1 before to choose one of these techniques.

Step VI, that establishes the criteria for land availability for WSUD technologies, its calculation for the standard range (cities in general) was based on the proportion between the 'maximum site coverage area' (50\%) and the 'minimum permeable area' $(20 \%)$, in conformity to many master plans in the 
world (Table 5). The percentages designated for Doncaster Hill in Table 5 are slightly different due to the building requirements present in the Manningham Planning Scheme (Step III in Table 4). In contrast to the BLUE Plan case applied for streetscape scale [17], there is no need to separate porous pavement from the other WSUD technologies in Step VI, because there is the same opportunity for most of these systems in lot-scale areas.

Table 5: $\quad$ Criteria for Lot-scale Developments.

\begin{tabular}{|c|c|c|c|}
\hline \multirow{2}{*}{$\begin{array}{l}\text { Land availability for } \\
\text { WSUD technologies }\end{array}$} & \multicolumn{3}{|c|}{ Housing Density (dw/ha) } \\
\hline & Low Density & Medium Density & High Density \\
\hline $\begin{array}{l}\text { Standard range } \\
\text { (cities in general) }\end{array}$ & $20 \%-50 \%$ & $20 \%-40 \%$ & $20 \%-30 \%$ \\
\hline In Doncaster Hill & $20 \%-40 \%$ & $20 \%-35 \%$ & $20 \%-30 \%$ \\
\hline
\end{tabular}

Moreover, the relation between housing density and available space as shown in this study demonstrates that when the lot is built in a high density model there is less opportunity for WSUD elements. This happens is because more families living in the same area require more facilities than just one family (e.g. description in the site layout analysis - Step IV). On the other hand, USEPA research [11] points out that high density allotments analysed on the regional scale can bring more benefits to the urban catchments than low density, such as less impervious surface, less stormwater runoff and less built covered area per dweller.

Table 6 presents the list of WSUD technologies and which ones are more suitable in lot-scale development. It was found that storage tanks, swales,

Table 6: $\quad$ Selection of WSUD Technologies into lot-scale (Step VII).

\begin{tabular}{cc}
\hline WSUD Technologies & Applicability for lot-scale \\
\hline 1. Gross pollutant traps & - \\
2. Sedimentation Basins & $\square$ \\
3. Swales or buffer strips & $\bullet$ \\
4. Bioretention systems & - \\
5. Sand Filters & 0 \\
6. Constructed Wetlands & $\square$ \\
7. Ponds & $\bullet$ \\
8. IS - Infiltration Systems (pits, basin \& trenches) & $\bullet$ \\
9. IS - Porous Pavement & $\bullet$ \\
10. Aboveground Storage Tanks - AST & - \\
11. Underground Storage Tanks - UST & \\
12. Aquifer Storage Recovery - ASR &
\end{tabular}

Legend: Best option $\bullet$; applicable $\circ$; applicable off-line $\square$; Not applicable - 
bioretention and infiltration systems (including porous pavement) are the best options for lot-scale, independently of the housing density required. Still, sedimentation basins and ponds can be applied as off-line systems (located out of the lot) as a part of the 'treatment train' (e.g. connected to other techniques and situated at the end of the street block).Although the BLUE Plan framework can be applied in the three different scales (lot, streetscape and precinct) of the planning process, these lot-scale procedures are not adequate for commercial urban areas with more than $80 \%$ of the building site coverage area - e.g. Central Business District (CBD) areas, typical commercial places without setbacks and/or permeable areas, buildings usually situated in lanes, etc.

The following illustrations show examples of the raingarden technique, also called bioretention systems. A raingarden is a specially prepared garden designed to receive and filter rain runoff from the roofs or impervious surfaces (such as outdoor paving or driveways).

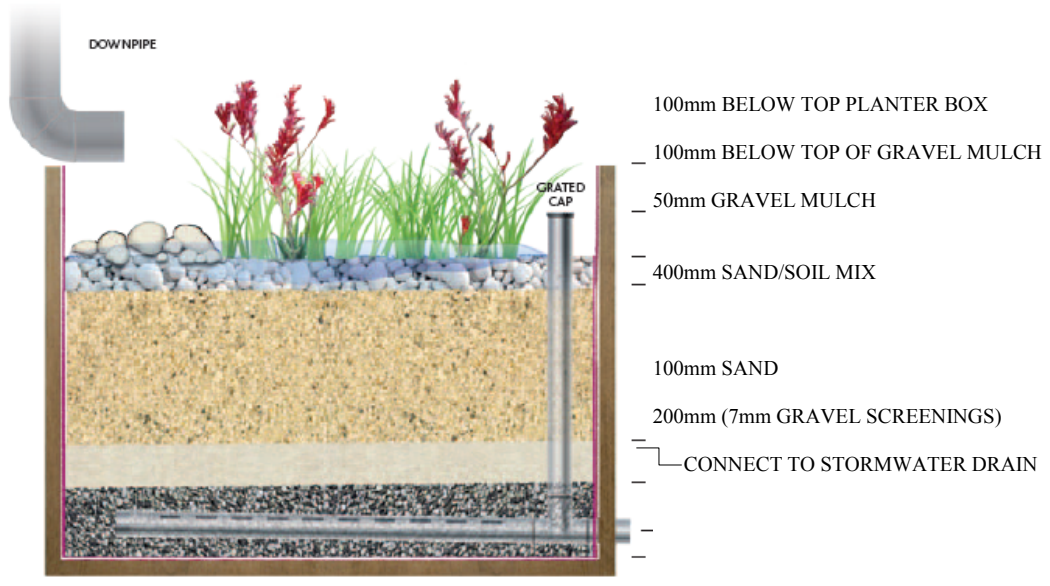

Figure 2: Schematic of a raingarden or bioretention system [18].

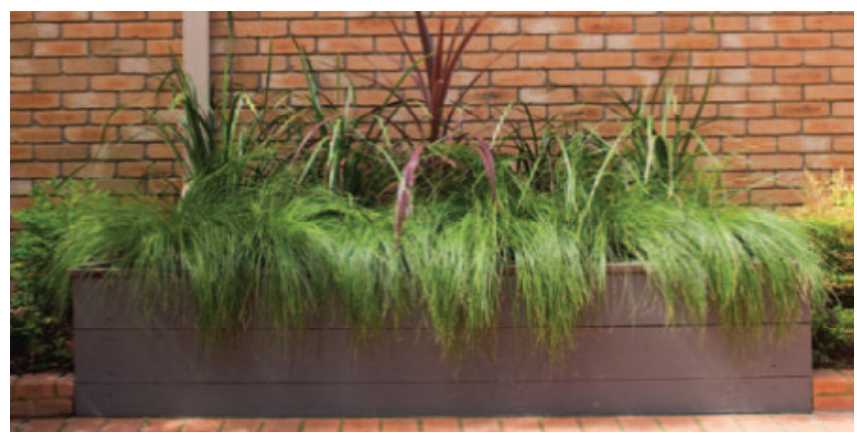

Figure 3: Photo of a raingarden or bioretention system in a house (lot-scale development) [18]. 


\section{Conclusions}

There is a need for procedures that can promote a better linkage between urban planners, landscape architects and WSUD engineering practices. BLUE Plan has started filling this gap through a framework that incorporates WSUD stormwater management systems into the urban planning and design process.

Although there is a complex relationship between housing density, the urban environment features and water resources, this framework covers all these topics providing potential urban space (according to specific land-use regulations) to fit WSUD elements into 3 distinct scales (lot, streetscape and precinct). This paper presents its application in a conceptual case for lot-scale developments in Doncaster Hill (Manningham City, Melbourne Metropolitan Region, Australia).

Results show that rainwater/stormwater tanks, bioretention systems, porous pavement and other infiltration technologies are more adequate to lot-scale developments, independent of the existing housing density. However, it is important to examine the WSUD design characteristics before implementing one of these, because the natural site conditions may limit the potential for implementing these WSUD technologies.

\section{Acknowledgements}

The authors thank the Brazilian Federal Agency for Support and Evaluation of Graduate Education (CAPES) for providing funding for this $\mathrm{PhD}$ research in Australia. Appreciation is also shown to Aston University (UK), especially with the contribution of the Operations and Information Management Group for the development of this work. We also thank IVIG/COPPE/UFRJ for funding our participation on this $5^{\text {th }}$ International Conference on Sustainable Development and Planning (WIT, 2011).

\section{References}

[1] Wong, T. H. F. (ed.). Australian Runoff Quality: A guide to Water Sensitive Urban Design. Engineers Australia, Canberra, 2006.

[2] CRCCH - Cooperative Research Centre for Catchment Hydrology. Model for Urban Stormwater Improvement Conceptualisation (MUSIC). User Guide, Monash University, Victoria, Australia, 2003.

[3] Deletic, A., Fletcher, T. D., Hatt, B., McCarthy, D. Stormwater Treatment Technologies: Latest advances, principles and Design Procedures. Civil Eng. Dept., Monash University, VIC, Australia, 2010.

[4] Melbourne Water, et al. WSUD Engineering Procedures: Stormwater. CSIRO, EPA Victoria, Australia, 2005.

[5] State Government of Victoria. Melbourne 2030 - Planning for sustainable growth. Department of Infrastructure, Victoria State, Australia, 2002.

[6] MCC, Manningham City Council. Doncaster Hill Strategy. MCC, Melbourne, Australia. Revised edition, 2004. 
[7] ABM, Association of Bayside Municipalities. Delivering WSUD: Final Report of Clean Stormwater - a Planning Framework. ABM, Melbourne, Australia, 2004.

[8] LaGro Jr., J. A. Site Analysis: a contextual approach to sustainable land planning and site design. John Wiley \& Sons, Inc. publishing, USA, $2^{\text {nd }}$ edition, 2008.

[9] Duany, A., Speck, J., Lydon, M. The smart Growth Manual. McGraw-Hill, Inc., USA, 2010.

[10] USEPA, United States Environmental Protection Agency, Development, Community and Environment Division. Protecting Water Resources with Smart Growth. Washington, DC: EPA 231-R-04-002, 2004.

[11] USEPA, United States Environmental Protection Agency, Development, Community and Environment Division. Protecting Water Resources with Higher-Density Development. Washington, DC: EPA 231-R-06-001, 2006.

[12] Government of South Australia. Understanding Residential Densities: A Pictorial Handbook of Adelaide Examples. Australia: 2006. Online, www.planning.sa.gov.au.

[13] MCC, Manningham City Council. Manningham Planning Scheme. Victorian State Gov., Australia, 2010.

[14] Rio Grande do Norte Government. Natal Master Plan, Brazil, 2009.

[15] Mato Grosso Government. Guarantã do Norte Master Plan, Brazil, 2011.

[16] ABS, Australian Bureau of Statistics. Housing Provision (Residential lot sizes of Metropolitan Melbourne). Australia, 2010.

[17] Nunes et al. Procedures for integrating Water Sensitive Urban Design (WSUD) technologies into site planning process: Criteria for streetscape scale applied in Melbourne region - Australia.12th International Conference on Urban Drainage. Porto Alegre, Brazil, 2011.

[18] Melbourne Water. Building a Raingarden. Victoria Government, Australia: 2010. Online melbournewater.com.au. 